\title{
Relationship between perimenopause symptoms and bone mineral density
}

\author{
Aida $^{1 *}$, Djaswadi Dasuki², Siswishanto Rukmono ${ }^{2}$ \\ Department of Obstetry and Gynecology, Universitas Gadjah Mada/Dr. Sardjito General \\ Hospital, Yogyakarta
}

\begin{abstract}
The menopausal transition or perimenopause is associated with numerous symptoms. Women entering perimonopause normally have menstrual irregular periods due to an imbalance of serum estradiol. Since the status of estrogen is known as an important determinant of bone mass density, menopausal symptoms can be an effective indicator of bone status in women. This study aimed to evaluate the relationship between perimenopause symptoms and bone mineral density (BMD). This was an observational study using cross-sectional design conducted during three months periode from June to August 2010 in Kalangan Village, Banguntapan, Bantul District. Subjects were women between the aged 46-55 years who fulfilled the inclusion and exclusion criteria. After underwent history taking, subjects underwent physical examination according to International Physical Activity Questionnaires (IPAQ). The BMD of subjects was than measured using dual-energy X-ray absorptiometry (DEXA). The relationship between perimenopause symptoms and BMD was then evaluated using multivariate analysis. The results showed that perimenopause symptoms increase abnormal BMD of subjects 1.38 times higher than those without perimenopause symptoms $(R R=1.38 ; 95 \% \mathrm{Cl} 1.39-13.78 ; \mathrm{p}=0.01)$. In conclusion, the perimenopause symptoms is associated with the high proportion of abnormal BMD in women.
\end{abstract}

\section{ABSTRAK}

Transisi menopause atau perimenopause dikaitkan dengan banyak gejala. Wanita yang memasuki perimenopause biasanya mengalami ketidakteraturan menstruasi karena ketidakseimbangan estradiol serum. Oleh karena status estrogen diketahui penting dalam menentukan densitas masa tulang, gejala menopause dapat menjadi indikator efektif status tulang pada wanita. Penelitian ini bertujuan untuk mengkaji hubungan antara gejala menopause dan densitas mineral tulang (DMT). Penelitian ini merupakan penelitian observasional dengan rancangan potong lintang yang dilakukan selama tiga bulan antara Juni sampai Agustus 2014 di Desa Kalangan, Banguntapan, Kabupaten Bantul. Subyek penelitian adalah wanita berumur 46-55 tahun yang memenuhi kriteria inklusi dan eksklusi. Setelah ditanyakan riwayat kesehatannya, subyek menjalanai pemeriksaan fisik menurut International Physical Activity Questionnaires (IPAQ). Densitas mineral tulang subyek kemudian ditetapkan dengan dual-energy X-ray absorptiometry (DEXA). Hubungan antara gejala perimenopause dan DMT dikaji menggunakan analisis multivariat. Hasil penelitian menunjukkan gejala perimenopause meningkatkan DMT abnormal 1,38 lebih tinggi pada wanita dengan gejala perimenopause dibandingkan wanita tanpa gejala perimenopause $(R R=1,38 ; 95 \% \mathrm{Cl}$ $1,39-13,78 ; p=0,01)$. Dapat disimpulkan bahwa gejala perimenopause berhubungan dengan tingginya DMT abnormal pada wanita.

Keywords: perimenopause - symptoms - bone mineral density - dual-energy x-ray absorptiometry - estrogen

\footnotetext{
* corresponding author: beautiful_life38@yahoo.com
} 


\section{INTRODUCTION}

The menopausal transition or perimenoupause is associated with numerous symptoms. Women entering perimenopause normally have menstrual irregular periods during 2 to 7 years before menopause due to an imbalance of serum estradiol. The decline in ovarian function is considered as a major factor in the development and manifestation of symptoms of menopause, as it can happen rapidly in some women and slower in others. Some women produce sufficient endogenous estrogen to remain without symptoms, while others show a variety of symptoms during climacterium. ${ }^{1-3}$

Since the status of estrogen is known as an important determinant of bone mass density, menopausal symptoms can be an effective indicator of bone status in women. Peri-and post-menopausal women show that hot flushes are significant and independent determinants of bone loss in radius. ${ }^{4}$ The radial bone loss as high as $9 \%$ per year occurs in women who reported symptoms, compared with no symptoms women. This evidence suggests that disturbances in ovarian function can adversely impact bone mass and increased the risk of osteoporosis. $^{5}$

To diagnose osteoporosis before the occurrence of fracture, examination that assesses bone density is necessary. Current examination with the most accurate, and relatively safe, fast and painless is using the dual-energy $\mathrm{X}$-ray absorptiometry (DEXA). The purpose of this study is to know the proportion of abnormal bone mineral density (BMD) in women with and without perimenopause symptoms. It is important to find other alternative methods, such as perimenopause symptoms in clinical findings, to determine the decrease of bone density or abnormal BMD early therefore perimenopausal fracture risk due to osteopenia or osteoporosis can be prevented. ${ }^{6}$

\section{MATERIALS AND METHODS}

\section{Subjects}

This was an observational study using cross-sectional design conducted during three months periode from June to August 2010 in Kalangan Village, Banguntapan, Bantul District. Inclusion criteria included women subjects between the age from 46 to 55 years who visiting Posyandu Lansia (Local Health Clinic for the Elderly) and willing to be research subjects. Exclusion criteria included subjects with apparent history of diabetes mellitus, neoplasma, rheumatoid arthritis, endocrine disorders, fractures, consumption of corticosteroids, or hormonal therapy. Minimum number of samples had been obtained from calculating a sample size of 86 subjects. The protocol of the study was approved by the Medical and Health Research Ethics Committee, Faculty of Medicine, Universitas Gadjah Mada, Yogyakarta.

\section{Procedure of study}

Study was coducted in three stages. First stage was history taking including presenting complaint, past medical history and history of taking anythings that are associated with risk factors the illness such as age, milk and coffee consumptions.

Second stage was physical examination including height and weight as well as physical activity. The physical activity was evaluated according to International Physical Activity Questionnaires (IPAQ). ${ }^{7}$ Furthermore, perimenopause symptoms were evaluated based anamnesis including hot flashes, irregular menstrual periods, urogenital discomfort and psychological problems as conducted by Salamone. ${ }^{8}$ Subjects reporting at least one menopausal symptom after a break menstrual period between 2-12 months were 
classified as perimenopause symptoms, whereas subjects reporting no symptoms were classified as without perimenopause symptoms.

Third stage was measurement of BMD using DEXA in Department of Radiology, Dr. Sardjito General Hospital. The value of BMD was used to calculate $\mathrm{T}$ scores which used to evaluate the mineral status of subject's bone with compared to normal women BMD according to World Health Organization criteria. ${ }^{9}$ Women with a $\mathrm{T}$ score at the $1 \mathrm{SD}$ (standard deviation) below normal women were considered as normal BMD, a T score between $1 \mathrm{SD}$ and 2.5 SD below normal women were considered as osteopenia and a T score at the 2.5 SD or more below normal women were considered as osteoporosis. Subjects would be considered abnormal BMD if they had osteopenia or osteoporosis.

\section{Statistical analysis}

Statistical tests used in this analysis were the multivariate with significance level of $p<0.05$ and confidence interval (CI) $95 \%$. The value of RR (risk ratio) was applied to determine the possible relationship between the independent variables with the dependent ones.

\section{RESULTS}

\section{Characteristics of subjects}

A total 86 subjects consisted of 60 subjects with perimenopause symptoms and 26 subjects without perimenopause symptoms were enrolled in this study. The characteristics subjects are shown in TABLE 1 . No significantly different in terms of age, BMI (body mass index), physical activity, consumption of coffee and consumption of milk were observed from both groups of subjects $(p>$ $0.05)$.

TABLE 1. Characteristics of subjects with and no perimenopause symptoms

\begin{tabular}{|c|c|c|c|c|c|}
\hline \multirow[t]{2}{*}{ Characteristics } & \multicolumn{2}{|c|}{$\begin{array}{c}\text { With } \\
\text { perimenopause } \\
\text { symptoms }\end{array}$} & \multicolumn{2}{|c|}{$\begin{array}{c}\text { No perimenopalise } \\
\text { symptoms }\end{array}$} & \multirow[t]{2}{*}{$\mathrm{p}$} \\
\hline & $\mathrm{N}$ & $\%$ & $\mathrm{~N}$ & $\%$ & \\
\hline \multicolumn{6}{|l|}{ Age (year) } \\
\hline - $46-50$ & 21 & 60.0 & 14 & 40.0 & \multirow{2}{*}{0.10} \\
\hline - $51-55$ & 39 & 76.5 & 12 & 35.3 & \\
\hline \multicolumn{6}{|l|}{$\mathrm{BMI}\left(<18.5 \mathrm{~kg} / \mathrm{m}^{2}\right)$} \\
\hline - No & 38 & 73.1 & 14 & 26.9 & \multirow{2}{*}{0.42} \\
\hline - Yes & 22 & 64.7 & 12 & 35.3 & \\
\hline \multicolumn{6}{|l|}{ Physical activity } \\
\hline - Mild & 31 & 73.8 & 11 & 26.2 & \multirow{2}{*}{0.43} \\
\hline \multicolumn{5}{|l|}{ Consumption of coffee } & \\
\hline - Never & 14 & 58.3 & 10 & 41.7 & \multirow{2}{*}{0.15} \\
\hline - Sometimesroutine & 16 & 71.2 & 16 & 25.8 & \\
\hline \multicolumn{6}{|l|}{ Consumption of milk } \\
\hline - Never & 34 & 66.7 & 17 & 33.3 & \multirow{2}{*}{0.45} \\
\hline - Sometimesroutine & 26 & 74.3 & 9 & 25.7 & \\
\hline
\end{tabular}

\section{The relationship between perimenopause symptoms and BMD}

TABLE 2 shows the relationship between $\mathrm{BMD}$ of subjects and the perimenopause symptoms. Among 54 subjects with perimenopause symptoms, 42 (77.8) subjects had abnormal BMD, whereas among 32 subjects without perimenopause symptoms, only 12 
(22.2\%) subjects had abnormal BMD. It was indicated that the incidence of abnormal BMD was significantly higher in subjects with perimenopause symptoms compared to in subjects without perimenopause symptoms $(\mathrm{p}<0.05)$. Moreover, the women with perimenopause symptoms may increase the risk of abnormal BMD 0.51 times higher than those without perimenopause symptoms $(\mathrm{RR}=0.51$; 95\%CI 0.27-0.96; $\mathrm{p}=0.04)$.

TABLE 2. The relationship between BMD of subjects and perimenopause symptoms

\begin{tabular}{lccccccc}
\hline \multirow{2}{*}{ Variables } & \multicolumn{2}{c}{$\begin{array}{c}\text { With } \\
\text { perimenopause } \\
\text { symptoms }\end{array}$} & $\begin{array}{c}\text { No perimenopause } \\
\text { symptoms }\end{array}$ & RR & $95 \% \mathrm{Cl}$ & $\mathrm{p}$ \\
\cline { 2 - 5 } & $\mathrm{N}$ & $\%$ & $\mathrm{~N}$ & $\%$ & & & \\
\hline Abnormal BMD & 42 & 77.8 & 12 & 22.2 & \multirow{2}{*}{0.51} & $0.27-0.96$ & $0.04 *$ \\
Normal BMD & 18 & 56.3 & 14 & 43.8 & 0.5 & \\
\hline
\end{tabular}

$*$ Significant if $\mathrm{p}<0.05$

\section{The relationship between risk factors of perimanopause symptoms and BMD}

TABLE 2 shows the relatioship between the risk factors of perimenopause symptoms and BMD. No significantly relationship between age, physical activity, consumption of coffee or milk with the occurrence of abnormal BMD. However, BMI of subjects was proven to be the risk factor of the abnormal BMD. Women with $\mathrm{BMI}<18.5 \mathrm{~kg} / \mathrm{m}^{2}$ had a 0.56 times higher of abnormal BMD than women with $>18.5 \mathrm{~kg} /$ $\mathrm{m}^{2}(\mathrm{RR}=0.56$; 95\%CI $0.41-0.77 ; \mathrm{p}=0.00)$.

TABLE 3. The relationship between risk factors of perimenopause symptoms and BMD

\begin{tabular}{|c|c|c|c|c|c|c|c|}
\hline \multirow[t]{2}{*}{ Variables } & \multicolumn{2}{|c|}{$\begin{array}{l}\text { Normal } \\
\text { BMD }\end{array}$} & \multicolumn{2}{|c|}{ Abnormal BMD } & \multirow[t]{2}{*}{ RR } & \multirow[t]{2}{*}{$95 \% \mathrm{Cl}$} & \multirow[t]{2}{*}{$\mathrm{p}$} \\
\hline & $\mathrm{N}$ & $\%$ & $\mathrm{~N}$ & $\%$ & & & \\
\hline $\begin{array}{l}\text { Age (year) } \\
\text { - } 46-50 \\
\text { - } 51-55\end{array}$ & $\begin{array}{l}29 \\
25\end{array}$ & $\begin{array}{l}56.9 \\
71.4\end{array}$ & $\begin{array}{l}22 \\
10\end{array}$ & $\begin{array}{l}43.1 \\
28.6\end{array}$ & 1.26 & $0.91^{-1} 1.73$ & 0.17 \\
\hline $\begin{array}{l}\text { BMI }<18.5 \mathrm{~kg} / \mathrm{m}^{2} \\
\text { - No } \\
\text { - Yes }\end{array}$ & $\begin{array}{l}25 \\
29\end{array}$ & $\begin{array}{l}48.1 \\
85.3\end{array}$ & $\begin{array}{r}27 \\
5\end{array}$ & $\begin{array}{l}51.9 \\
14.7\end{array}$ & 0.56 & $0.41-0.77$ & $0.00 *$ \\
\hline $\begin{array}{l}\text { Physical activity } \\
\text { - Mild } \\
\text { - } \quad \text { Moderate-severe }\end{array}$ & $\begin{array}{l}28 \\
26\end{array}$ & $\begin{array}{l}66.7 \\
59.1\end{array}$ & $\begin{array}{l}14 \\
18\end{array}$ & $\begin{array}{l}33.3 \\
40.9\end{array}$ & 1.13 & $0.81-1.56$ & 0.47 \\
\hline $\begin{array}{l}\text { Consumption of coffee } \\
\text { - Sometinnes-routine } \\
\text { - Never }\end{array}$ & $\begin{array}{l}38 \\
16\end{array}$ & $\begin{array}{l}61.3 \\
66.7\end{array}$ & $\begin{array}{c}24 \\
8\end{array}$ & $\begin{array}{l}38.7 \\
33.3\end{array}$ & 0.92 & $0.65-1.29$ & 0.65 \\
\hline $\begin{array}{l}\text { Consumption of milk } \\
\text { - Sometimes-routine } \\
\text { - Never }\end{array}$ & $\begin{array}{l}18 \\
36\end{array}$ & $\begin{array}{l}51.4 \\
70.6\end{array}$ & $\begin{array}{l}17 \\
15\end{array}$ & $\begin{array}{l}48.6 \\
29.4\end{array}$ & 0.73 & $0.51-1.05$ & 0.07 \\
\hline
\end{tabular}

*Significant if $\mathrm{p}<0.05$ 


\section{Multivariate analysis}

TABLE 3 shows the multivariate analysis of the relatioship between the risk factors of perimenopause symptoms and BMI and the occurrence of abnormal BMD. Perimenopause symptoms and BMI were proven to be independent risk factors of the occurence of BMD. Women with perimenopause symptoms had a 1.38 times higher of abnormal BMD than those without perimenopause symptoms $(\mathrm{RR}=1.38 ; 95 \% \mathrm{CI} 1.39-13.78 ; \mathrm{p}=0.01)$. Furthermore, women with BMI $<18.5 \mathrm{~kg} / \mathrm{m}^{2}$ had a 0.56 times higher of abnormal BMD than women with $>18.5 \mathrm{~kg} / \mathrm{m}^{2}(\mathrm{RR}=0.56 ; 95 \% \mathrm{CI}$ $0.03-0.39 ; \mathrm{p}=0.00)$.

TABLE 4. Multivariate analysis between BMI and perimenopause symptoms

\begin{tabular}{lccccc}
\hline Variables & $\mathrm{B}$ & $\mathrm{SE}$ & $\mathrm{RR}$ & $95 \% \mathrm{Cl}$ & $\mathrm{p}$ \\
\hline Perimenopause symptoms & 1.18 & 0.58 & 1.38 & $1.39-13.78$ & $0.01^{*}$ \\
BMI & -2.17 & 0.62 & 0.56 & $0.03-0.39$ & $0.00^{*}$ \\
\hline
\end{tabular}

*Significant if $p<0.05$

\section{DISCUSSION}

This study showed that there was relationship between perimenopause symptoms and abnormal BMD women. Studies concerning the BMD in peri and postmenopausal women have been reported by some authors. Jacka et al. ${ }^{10}$ reported that in perimenopausal women with self-reported depression was associated with lower BMD at the hip. Another study reported that postmenopausal women had significantly lower mean BMD and a higher incidence of osteoporosis compared with the premenopausal women. Moreover, age and a greater postmenopausal duration showed a significant negative association with BMD. ${ }^{11}$ The BMD demonstrates an accelerated rate of bone loss during the menopausal transition. The greatest reduction occurs in the year before the final menstrual period and the first 2 years thereafter. $^{12}$

The perimenopausal period in women is characterized by various somatic, vasomotor, sexual and psychological symptoms. ${ }^{13}$ Many symptoms have been identified and associated with perimenopause like hot flashes, hot flushes, night sweats, irregular heart beat, mood swings, trouble sleeping through the night, loss of libido, vagina dryness, crashing fatigue, gastrointestinal distress, difficulty concentration, mental confusion, depression etc. ${ }^{4,5,13}$ These symptoms are associated with a low progresteron to estrogen ratio (estrogen dominance). In addition, testoterone levels may also start to decline before the last menstrual and estrogen is often last hormone to decline. ${ }^{3,13}$

Estrogen plays an important role in the growth and maturation of bone as well as in the regulation of bone turnover in adult bone. The major physiological effect of estrogen is to inhibit bone resorption. Bone cells have two kinds of intracellular steroid receptors for estrogen. When estrogen binds to the receptors, various genes become active. Estrogen also has effects that do not depend on activating the DNA. Estrogen effects may be mediated in part by growth factors and interleukins (IL). For example, IL6 is a potent stimulator of bone resorption, and estrogen blocks the osteoblast's synthesis of IL 6. Estrogen may also antagonize the IL 6 receptors. ${ }^{12,14}$ 
The decline of estrogen levels during perimenopause causes several symptoms lead to an increase in bone resorption and reduction in BMD. ${ }^{3,15}$ This study found that the perimenopause symptoms is associated with the lower BMD in women which is suported by others studies. ${ }^{10-12}$ Therefore, perimenopause symptoms may can be used as BMD marker in perimonopausal women. This clinical symptoms will be easy to be implemented in clinical setting. However, further study should be performed with larger sample size to validate the relationship between perimenopause symptoms and BMD in women. The finding will give benefit to take action in prevention of perimenopause fracture risk.

\section{CONCLUSION}

In conclusion, the perimenopause symptoms is associated with the high proportion of abdnormal BMD in women. The proportion of abnormal BMD in the women with perimenopasue symptoms is higher compared to the women without perimenopasue symptoms

\section{ACKNOWLEDGEMENTS}

Authors would like to thank Head of Department of Obstetry and Gynecology as well as Head of Department of Radiology, Universitas Gadjah Mada/Dr. Sardjito General Hospital, Yogyakarta for his permission to conduct this study. We would also like to thank all subjects who have participated in this study.

\section{REFERENCES}

1. Simpson ER, Davis SR. Minireview: aromatase and the regulation of estrogen biosynthesis - some new perspectives. Endocrinology 2001; 142(11): 4589-94.

2. Davison SL, Bell R, Donath S, Montalto JG, Davis SR. Androgen levels in adult females: changes with age, menopause, and oophorectomy. J Clin Endocrinol Metab 2005; 90(7):3847-53.
3. Hale GE, Burger HG. Hormonal changes and biomarkers in late reproductive age, menopausal transition and menopause. Best Pract Res Clin Obstetr Gynaecol 2009; 23: 7-23.

4. Naessen T, Persson I, Ljunghall S, Bergstrom R. Women with climacteric symptoms: a target group for prevention of rapid bone loss and osteoporosis. Osteoporosis Int 1992; 2(5):22531.

5. Salamone L, Gregg E, Wolf RL, Eipsten RS, Black $\mathrm{D}$, Palermo L, et al. Are menopausal symptoms associated with bone mineral density and changes in bone mineral density in premenopausal women? Maturitas 1998; 29(2):179-87.

6. Trijoto I, Isbagio H, Setiyohadi B, Soegondo S, Kusumawidjaja K, Ariawan I. The diagnostic value of combined risk faktor analysis and radiological imaging in determining osteoporosis in postmenopausal women. Acta Med Indones 2005; 37(1):26-32.

7. IPAQ. Guidelines for date processing and analysis of the International Physical Activity Questionare (IPAQ) [internet]. 2005 [updated 2011 Feb 10; cited 2011 Apr 10]. Available from: http:// www.ipaq.ki.se/scoring.pdf

8. Salamone L, Gregg E, Wolf RL, Eipsten RS, Black $\mathrm{D}$, Palermo L, et al. Are Menopausal symptoms associated with bone mineral density and changes in bone mineral density in premenopausal women. Maturitas 1998; 29(2):179-87.

9. World Health Organization. Assessment of fracture risk and its application to screening for postmenopausal osteoporosis. Report of a WHO study group. World Health Organ Tech Rep Ser 1994; 843:1-129.

10. Jacka FN, Pasco JA, Henry MJ, Kotowicz MA, Dodd S, Nicholson GC, et al. Depression and bone mineral density in a community sample of perimenopausal women: Geelong Osteoporosis Study. Menopause 2005; 12(1):88-91.

11. Lim PS, Ong FB, Adeeb N, Seri SS, Noor-Aini MY, Shamsuddin K, et al. Bone health in urban midlife Malaysian women: risk factors and prevention. Osteoporos Int 2005; 16(12):206979. 
12. Lo JC, Burnett-Bowie SA, Finkelstein JS. Bone and the perimenopause. Obstet Gynecol Clin North Am 2011; 38(3):503-17.

13. Carr MC. The emergence of the metabolic syndrome with menopause. J Clin Endocrinol Metab 2003;88(6):2404-11.
14. Väänänen HK, Härkönen PL. Estrogen and bone metabolism. Maturitas 1996; 23(Suppl):S65-9.

15. Ebeling PR, Atley LM, Guthrie JR, Burger HG, Dennerstein L, Hopper JL, et al. Bone turnover markers and bone density across the menopausal transition. J Clin Endocrinol Metab 1996; 81(9):3366-71. 